\title{
Article \\ Effects of Different $\beta$-Lactam Antibiotics on Indirect Tomato (Solanum lycopersicum L.) Shoot Organogenesis and Agrobacterium tumefaciens Growth Inhibition In Vitro
}

\author{
Nataliya V. Varlamova ${ }^{1}$, Yuliya I. Dolgikh ${ }^{1}$, Andrey O. Blinkov ${ }^{1}$, Ekaterina N. Baranova ${ }^{2,3}$ (D) and \\ Marat R. Khaliluev 1,4,*(D) \\ 1 Laboratory of Plant Cell Engineering, All-Russia Research Institute of Agricultural Biotechnology, \\ Timiryazevskaya 42, 127550 Moscow, Russia; nv_varlamova@rambler.ru (N.V.V.); yulia53@list.ru (Y.I.D.); \\ aoblinkov@gmail.com (A.O.B.) \\ 2 Laboratory of Cell Biology, All-Russia Research Institute of Agricultural Biotechnology, Timiryazevskaya 42, \\ 127550 Moscow, Russia; greenpro2007@rambler.ru \\ 3 Laboratory of Plant Protection, N.V. Tsitsin Main Botanical Garden of Russian Academy of Sciences, \\ Botanicheskaya 4, 127276 Moscow, Russia \\ 4 Department of Biotechnology, Institute of Agrobiotechnology, Russian State Agrarian University—Moscow \\ Timiryazev Agricultural Academy, Timiryazevskaya 49, 127550 Moscow, Russia \\ * Correspondence: marat131084@rambler.ru; Tel.: +7-(499)-977-31-41
}

\section{check for}

updates

Citation: Varlamova, N.V.; Dolgikh, Y.I.; Blinkov, A.O.; Baranova, E.N.; Khaliluev, M.R. Effects of Different $\beta$-Lactam Antibiotics on Indirect Tomato (Solanum lycopersicum L.) Shoot Organogenesis and Agrobacterium tumefaciens Growth Inhibition In Vitro. Antibiotics 2021, 10, 660. https:// doi.org/10.3390/antibiotics10060660

Academic Editor: Luca Vitale

Received: 25 April 2021

Accepted: 26 May 2021

Published: 1 June 2021

Publisher's Note: MDPI stays neutral with regard to jurisdictional claims in published maps and institutional affiliations.

Copyright: (c) 2021 by the authors. Licensee MDPI, Basel, Switzerland. This article is an open access article distributed under the terms and conditions of the Creative Commons Attribution (CC BY) license (https:// creativecommons.org/licenses/by/ $4.0 /)$.
Abstract: A $\beta$-lactams that act by inhibiting the bacterial cell wall biosynthesis are one of the most common classes of antibiotics applied to suppress the growth of latent bacterial infection associated with the plant tissue culture, as well as in the Agrobacterium-mediated transformation techniques. Plant sensitivity to antibiotics usually is species-, genotype-, or even tissue-specific and mainly depends on concentrations, growth conditions, and culture system. In the presented article, we estimated a comparative effect of four $\beta$-lactam antibiotics (Claforan ${ }^{\circledR}$, timentin, amoxicillin, and Amoxiclav $^{\circledR}$ ) at different concentrations in an agar-solidified Murashige and Skoog (MS) culture medium supplemented with $5 \mathrm{mg} \mathrm{L}^{-1}$ 6-benzylaminopurine (6-BA) and $0.1 \mathrm{mg} \mathrm{L}^{-1}$ indole-3-acetic acid (IAA) on in vitro callus induction and shoot organogenesis from hypocotyl and cotyledon explants of two tomato cultivars (Rekordsmen, Moryana). The role of clavulanic acid in combination with amoxicillin (Amoxiclav ${ }^{\circledR}$ ) in the shoot organogenesis frequency and number of shoots per explant has been demonstrated. Additionally, the growth inhibition of Agrobacterium tumefaciens AGL0 strain according to agar disk-diffusion assay was studied. As a result, both stimulatory (timentin, amoxicillin, and Amoxiclav ${ }^{\circledR}$ ) and inhibitory (Claforan ${ }^{\circledR}$ ) effects of $\beta$-lactam antibiotics on in vitro morphogenetic responses of tomato were noted. It was found that clavulanic acid, which is part of the commercial antibiotic Amoxiclav ${ }^{\circledR}$, significantly increased the shoot regeneration frequency from cotyledon and hypocotyl explants of Rekordsmen tomato cultivar. Possible reasons for the stimulating effect of clavulanic acid on the induction of shoot organogenesis are discussed. According to agar disk-diffusion assay, the maximum diameter of growth inhibition zones $(43.9 \mathrm{~mm})$ was identified using $200 \mathrm{mg} \mathrm{L}^{-1}$ timentin. The in vitro antibacterial activity of tested $\beta$-lactam antibiotics was arranged in the following order: timentin $>$ Claforan $^{\circledR}>$ amoxicillin $\geq$ Amoxiclav ${ }^{\circledR}$. Thus, to suppress the growth of internal and latent bacterial infection of tomato plant tissue culture, as well as for transformation of Moryana and Rekordsmen cultivars by A. tumefaciens strain AGL0, we recommend adding of $100-200 \mathrm{mg} \mathrm{L}^{-1}$ timentin or $400-800 \mathrm{mg} \mathrm{L}^{-1}$ Amoxiclav $^{\circledR}$ to the shoot induction medium.

Keywords: Solanum lycopersicum L.; Claforan ${ }^{\circledR}$; timentin; amoxicillin; Amoxiclav ${ }^{\circledR}$; clavulanic acid; callus induction; shoot regeneration; agar disk-diffusion method 


\section{Introduction}

Agrobacterium-mediated transformation is the commonly used method for stable integration of foreign genes into the genome and consequent generations of tomato (Solanum lycopersicum L.) and many other dicotyledonous transgenic plants [1,2]. Direct methods to introduce of foreign DNA into the tomato genome, such as bioballistic transformation [3,4], microinjection-based transformation [5], electroporation-mediated transformation [6], and PEG-mediated protoplast transformation [7,8], are used much less frequently. This is due to the fact that Agrobacterium-mediated transformation has a number of significant advantages compared with direct methods of introducing exogenous DNA. These include the relative simplicity of transformation procedure and lower cost of equipment, high competence of tomato somatic cells for Agrobacterium infection, the ability to transfer a large DNA fragments with low-copy number transgene integration into the plant genome, and stable Mendelian inheritance [2,9].

Regardless of the genetic transformation techniques, the regeneration of full-fledged and fertile shoots from various tomato explants in vitro is a prerequisite. Most frequently, shoot regeneration is achieved from tomato somatic cells via indirect organogenesis through the callus phase [1,10-12]. Other approaches for shoot regeneration in vitro in tomato through direct organogenesis $[13,14]$ as well as direct or indirect somatic embryogenesis $[12,15-17]$ are much less common.

Plant morphogenesis is a complicated and integrated process, a regulation which is carried out at the cellular, tissue, organ, and organismal level. The in vitro morphogenetic capacity of various somatic tomato tissues is genetically controlled [18-21]. The morphogenetic responses of tomato somatic cells during Agrobacterium-mediated transformation highly depends on the genotype, physiological age and explant type, culture medium as well as quantitative and qualitative component of plant growth regulators (PGRs), Agrobacterium strain, type of plasmid vector, and different physical and cultural conditions, as well as other factors $[1,22,23]$.

A. tumefaciens is a gram-negative soil bacterium that is pathogenic to plant tissue cultures [2]. Therefore, Agrobacterium-mediated transformation can undoubtedly be considered a combination of biotic (contamination of pathogenic bacteria) and abiotic (explant wounding, prolonged cultivation on culture medium supplemented with PGRs and antibiotics at high concentrations for callus induction, shoot regeneration, as well as selection of transgenic plants) stress factors that has a complex multiple effect [24]. Stressful conditions initiate primary stress-induced response, displayed in reactive oxygen species generation and activation of signaling cascades, which ultimately significantly reduces the regeneration and transformation capacity [25]. It was previously demonstrated that the nanomolar concentrations of antioxidant SkQ1, which penetrates the cell membrane and accumulates in mitochondria, stimulated indirect shoot organogenesis of Zea mays L., Triticum aestivum L., Saccharum officinarum L., and Medicago sp. [26].

Co-cultivation of tomato explants with Agrobacterium is carried out mainly at a low temperature $\left(15-18^{\circ} \mathrm{C}\right)$ in darkness for $48-72 \mathrm{~h}$. It is believed that during this time period, the entire cycle of Agrobacterium-mediated transformation occurs, from T-DNA excision to insertion into the plant genome. An increase in the co-cultivation period (96 $\mathrm{h}$ or more) and temperature leads to intensive multiplication of bacterial cells, premature contamination, and death of explants $[27,28]$. Tissue browning and necrotization of explants inoculated with Agrobacterium in the early stages of cultivation are due to plant cells' death caused by the plant-pathogen interaction [29]. In this regard, subculturing explants after the co-cultivation stage on a culture medium supplemented with antibiotics is essential for suppressing Agrobacterium growth.

$\beta$-lactams (penicillins, cephalosporins, carbapenems, monobactams, and $\beta$-lactamase inhibitors) that act by inhibiting the bacterial cell wall biosynthesis $[30,31]$ are one of the most common classes of antibiotics applied to suppress the growth of internal and latent bacterial infection associated with the plant tissue culture, as well as in the Agrobacteriummediated transformation techniques. Clavulanic acid derived from Streptomyces clavuligerus 
is a $\beta$-lactam molecule that has little intrinsic antibacterial activity that functions as a mechanism-based $\beta$-lactamase inhibitor. Potassium clavulanate (clavulanic acid as a salt of potassium) combined with $\beta$-lactam antibiotics such as amoxycillin (trade names Augmentin ${ }^{\circledR}$, Amoxiclav $^{\circledR}$, Clavamox $^{\circledR}$, and others) or ticarcillin (trade name Timentin ${ }^{\circledR}$ ) to fight antibiotics resistance by preventing their degradation by $\beta$-lactamase enzymes, broadening their spectrum of susceptible to bacterial infections [32]. The choice of antibiotic is based on the following requirements: (1) affordable price, (2) highly bacteriostatic and bactericidal effects, (3) no negative effect on the growth and morphogenesis of plant tissue cultures, (4) stability in liquid or solidified culture medium; (5) stability in stock solutions after storage at -20 or $-80^{\circ} \mathrm{C}$ and periodic thaw-freeze cycles [33].

The presented article is devoted to the comparative effect of various $\beta$-lactam antibiotics, such as cefotaxime, amoxycillin, and ticarcillin, on in vitro callus induction and shoot organogenesis of two tomato cultivars (Rekordsmen, Moryana), as well as growth inhibition of the Agrobacterium tumefaciens AGL0 strain. In addition, the role of clavulanic acid in the form of a potassium salt on tomato morphogenesis was evaluated.

\section{Results}

2.1. The Effects of Different $\beta$-Lactam Antibiotics on In Vitro Tomato Morphogenesis

2.1.1. Callus Induction and Frequency of Its Formation

Cotyledon and hypocotyl explants of both tomato cultivars increased in size at the beginning of passaging when cultivated on Murashige and Skoog medium (MS) with PGRs (control MS1) and experimental culture media supplemented with a $\beta$-lactam antibiotic (MS2-MS9) (Table 1). Thickening of the overgrown tissues on explants could be observed already on the fifth day of cultivation, from which the callus was subsequently formed. Dense and light green calli were formed on the 10-12 days after planting on the abaxial part of cotyledons, as well as on the edge of cotyledon petioles. The formation of callus tissue on tomato hypocotyl occurred on the entire explant surface. The histological analysis of callus tissue revealed formation of a meristematic zone among hypertrophied cortical parenchyma cells. The meristematic zones consist of meristematic cell masses as well as de novo formed tracheal elements located in their central part (Figure 1).

The results of the three-way ANOVA test showed statistical differences at 5\% significance level in callus formation frequency between different tomato explants and the studied culture media. In addition, the differences were significant for the interaction of factors "culture medium $\times$ genotype", "culture medium $\times$ explant", "genotype $\times$ explant", and "culture medium $\times$ explant $\times$ genotype" (Table S1). The frequency of callus formation from hypocotyl and cotyledon explants of Moryana and Rekordsmen cultivars on control MS1 culture medium was $58.0 \%$ and $75.0 \%$, as well as $83.6 \%$ and $91.3 \%$, respectively (Figure 2).

Table 1. Types and concentrations of $\beta$-lactam antibiotics used in MS culture media for in vitro callus induction and shoot organogenesis of tomato.

\begin{tabular}{|c|c|c|c|c|c|c|c|c|c|}
\hline \multicolumn{2}{|c|}{ Culture Medium } & MS2 & MS3 & MS4 & MS5 & MS6 & MS7 & MS8 & MS9 \\
\hline \multirow{2}{*}{ 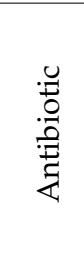 } & brand name & \multicolumn{2}{|c|}{$\begin{array}{c}\text { Claforan }^{\circledR} \\
\text { Sanofi-Aventis (France) }\end{array}$} & \multicolumn{2}{|c|}{$\begin{array}{c}\text { Timentin, } \\
\text { PhytoTechnology } \\
\text { Laboratories (USA) }\end{array}$} & \multicolumn{2}{|c|}{$\begin{array}{c}\text { Amoxicillin, } \\
\text { PhytoTechnology } \\
\text { Laboratories (USA) }\end{array}$} & \multicolumn{2}{|c|}{$\begin{array}{c}\text { Amoxiclav }^{\circledR} \\
\text { Lek d.d. (Slovenia) }\end{array}$} \\
\hline & generic name & \multicolumn{2}{|c|}{ Cefotaxime sodium } & \multicolumn{2}{|c|}{$\begin{array}{c}\text { Ticarcillin } \\
\text { disodium + clavulanate } \\
\text { potassium }(15: 1)\end{array}$} & \multicolumn{2}{|c|}{ Amoxicillin } & \multicolumn{2}{|c|}{$\begin{array}{l}\text { Amoxicillin }+ \\
\text { clavulanate potassium }\end{array}$} \\
\hline \multicolumn{2}{|c|}{ Concentration, $\mathrm{mg} \mathrm{L}^{-1}$} & 400 & 800 & 100 & 200 & 200 & 400 & 400 & 800 \\
\hline
\end{tabular}



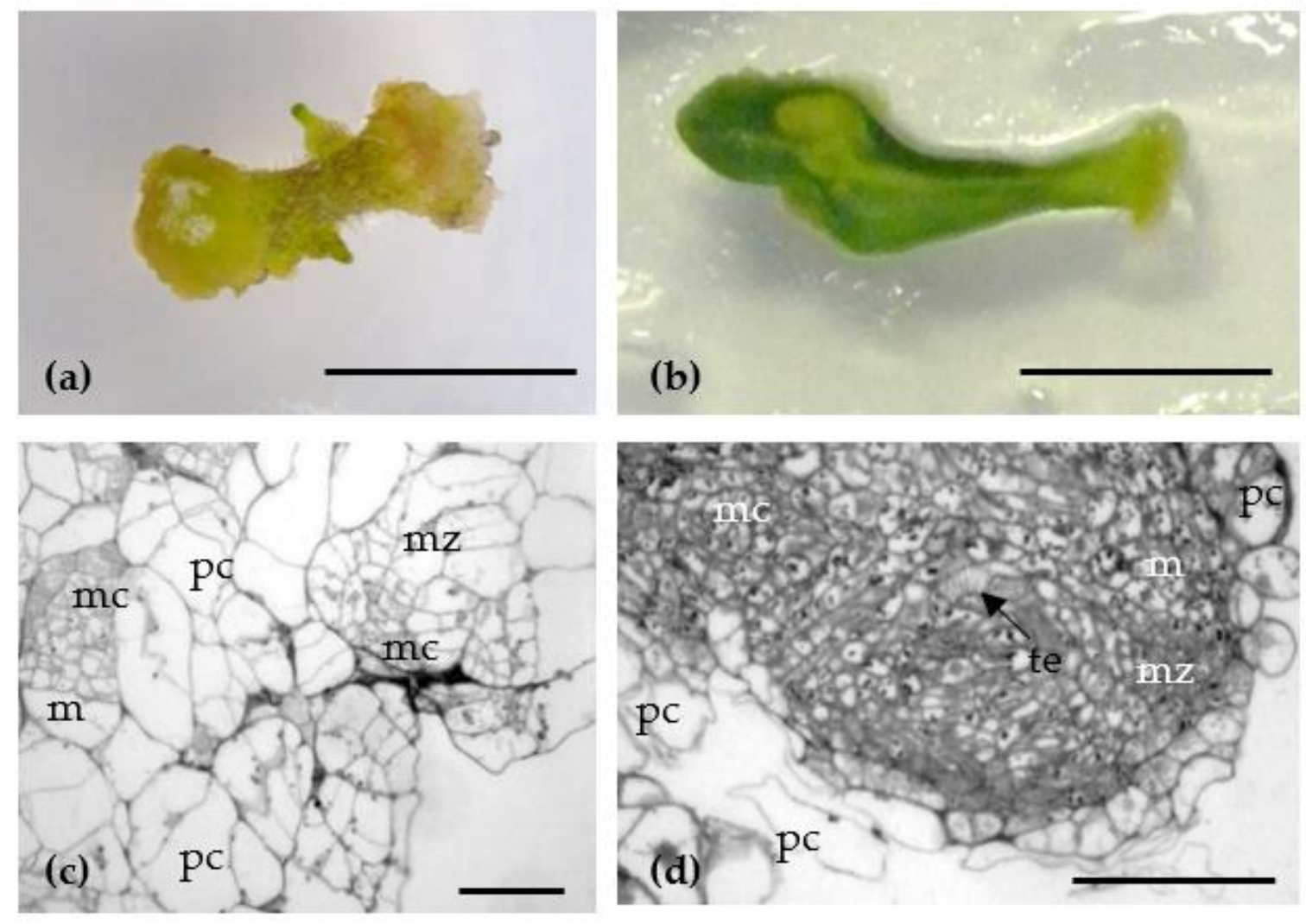

Figure 1. Callus formation from hypocotyl (a) and cotyledon (b) explants on MS1 culture media supplemented with $5 \mathrm{mg} \mathrm{L}^{-1}$ 6-benzylaminopurine (6-BA) and $0.1 \mathrm{mg} \mathrm{L}^{-1}$ indole-3-acetic acid (IAA) and its histological analysis (c,d). Abbreviations: $\mathrm{mz}$-meristematic zone; mc - meristematic cell; pc—parenchyma cell; te—-tracheal element. Bars-1 cm (a,b) and $50 \mu \mathrm{m}(\mathbf{c}, \mathrm{d})$.

Significant differences in the frequency of callus formation between hypocotyl (97.6\%) and cotyledon $(67.0 \%)$ explants in Moryana cultivar were revealed on the culture medium (MS9) supplemented with $800 \mathrm{mg} \mathrm{L}^{-1}$ of Amoxiclav ${ }^{\circledR}$. In contrast, a dramatic inhibition of callus formation $(8.5 \%)$ from cotyledons of Rekordsmen tomato cultivar was observed during the cultivation on a MS3 medium supplemented with a high concentration of cefotaxime. No significant differences were found between the culture media on the average callus formation frequency for two explant types of Moryana tomato cultivar. Similar data were noted for the Rekordsmen cultivar, except for MS3 and MS8 culture media, on which the values of callus formation frequency were, respectively, significantly lower and higher in comparison with the control.

\subsubsection{Efficiency of Tomato Shoot Organogenesis}

The efficiency of tomato shoot organogenesis was assessed by the frequency of somatic organogenesis (Table 2), as well as the average number of regenerated shoots per explant (Table 3). The frequency of tomato shoot organogenesis from hypocotyl and cotyledon explants of Moryana and Rekordsmen cultivars on control MS1 culture medium supplemented with PGRs was $4.4 \%$ and $1.5 \%$, as well as $67.1 \%$ and $42.7 \%$, respectively (Table 2). When explants of the Moryana cultivar were cultured on most media with the addition of antibiotics, no significant differences were found in the shoot organogenesis frequency both in comparison with control and among themselves according to Duncan's multiple range test. The exception was MS4 and MS6 culture media supplemented with $100 \mathrm{mg} \mathrm{L}^{-1}$ timentin and $200 \mathrm{mg} \mathrm{L}^{-1}$ amoxicillin, respectively, which stimulated the shoots organogenesis from hypocotyl explants, increasing their frequency by 8.5 and 6.8 times. In contrast to the MS7 culture medium containing $400 \mathrm{mg} \mathrm{L}^{-1}$ amoxicillin, the MS8 medium, characterized by the presence of clavulanic acid in the commercial antibiotic Amoxiclav ${ }^{\circledR}$, 
significantly increased the shoot regeneration frequency from cotyledon and hypocotyl explants of Rekordsmen tomato cultivar.

A more pronounced effect of $\beta$-lactam antibiotics on the induction of somatic shoot organogenesis from different tomato explants was demonstrated for Rekordsmen cultivar. Adding timentin (MS4, MS5), Amoxiclav ${ }^{\circledR}$ (MS8, MS9), and amoxicillin at a concentration of $200 \mathrm{mg} \mathrm{L}^{-1}$ (MS6) to the culture medium leads to a significant increase in the shoot organogenesis frequency of from hypocotyl explants (17.6-77.8\%). A similar response was observed for the cotyledon explants of Rekordsmen cultivar in the MS5, MS8 and MS9 culture medium. At the same time, the frequency of somatic shoot organogenesis from cotyledon explants on a culture medium containing Amoxiclav ${ }^{\circledR}$ (MS8, MS9) was $100 \%$ compared with control treatment $(42.7 \%)$, and one significantly exceeded other experimental variants. Cultivation of cotyledon explants on MS2 medium supplemented with $400 \mathrm{mg} \mathrm{L}^{-1}$ Claforan $^{\circledR}$ dramatically reduced rates of shoot organogenesis $(1.2 \%)$, while a twofold increase in its concentration completely inhibited the regenerative process.
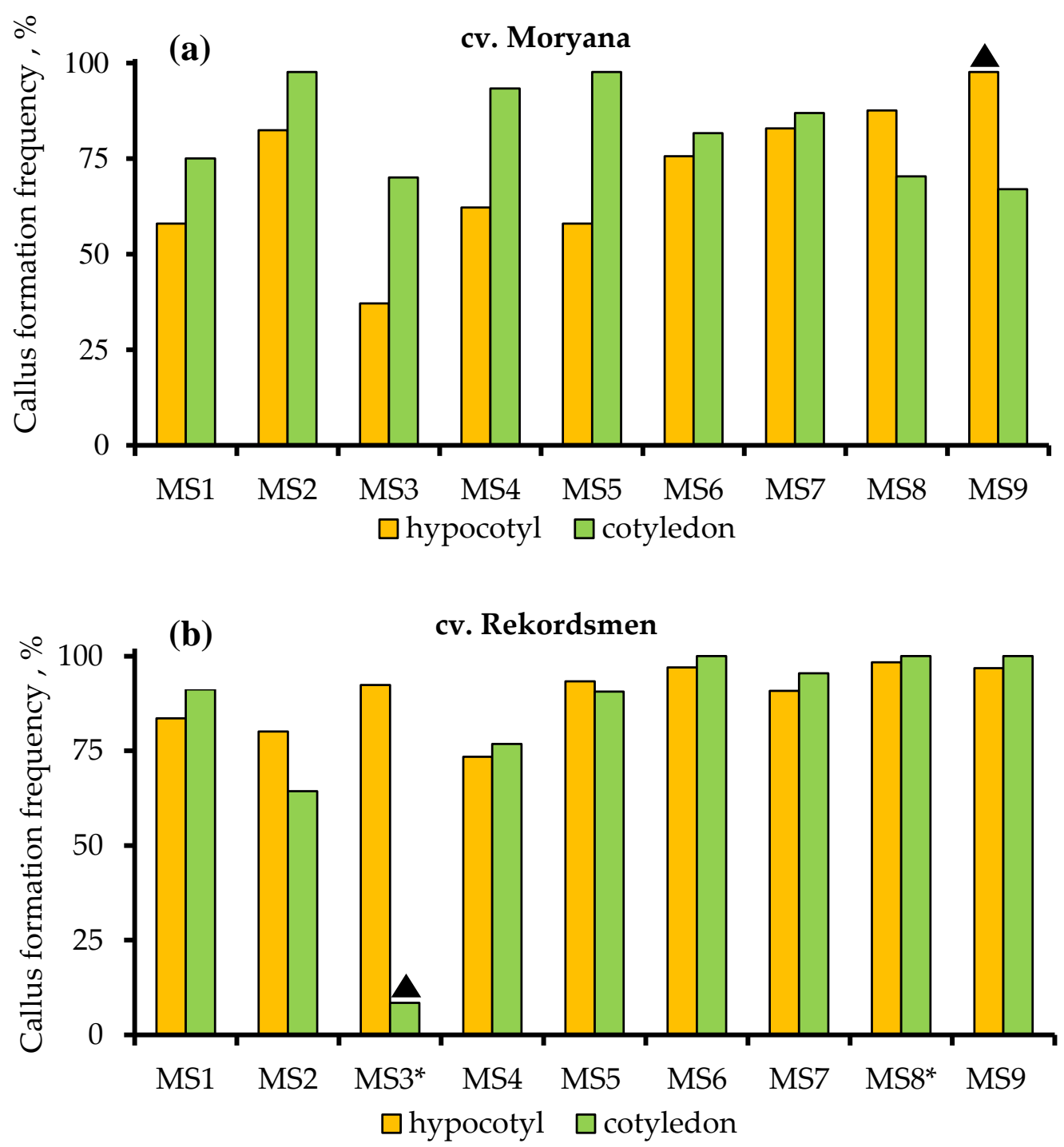

Figure 2. Influence of MS culture media supplemented with different types and concentrations of $\beta$-lactam antibiotics (MS2-MS9) on the callus formation frequency from hypocotyl and cotyledon explants of tomato cv. Moryana (a) and Rekordsmen (b). Abbreviations: $\mathbf{\Delta - v a r i a n t s ~ o f ~ c u l t u r e ~ m e d i a ~}$ that have significant differences $(\alpha=0.05)$ between cotyledon and hypocotyl explants; ${ }^{*}$-variants of culture media significantly different from the control treatment (MS1). 
Table 2. The effects of genotype, explant type, and culture medium components on the frequency of tomato shoot organogenesis in vitro.

\begin{tabular}{|c|c|c|c|c|c|c|c|c|c|}
\hline \multirow{3}{*}{$\begin{array}{l}\text { Culture } \\
\text { Medium }\end{array}$} & \multirow{3}{*}{\multicolumn{2}{|c|}{$\begin{array}{l}\text { Antibiotic and Its } \\
\text { Concentration, } \\
\mathrm{mg} \mathrm{L}^{-1}\end{array}$}} & \multicolumn{7}{|c|}{ Frequency of Shoot Organogenesis, \% } \\
\hline & & & \multicolumn{3}{|c|}{ cv. Moryana } & \multicolumn{3}{|c|}{ cv. Rekordsmen } & \multirow{2}{*}{$\begin{array}{c}\text { Mean } \\
\text { (Culture }^{\text {Medium) }} \\
\text { Medium }^{3}\end{array}$} \\
\hline & & & Hypocotyls & Cotyledons & Mean $^{2}$ & Hypocotyls & Cotyledons & Mean & \\
\hline MS1 & \multicolumn{2}{|c|}{ - } & $4.4^{1} \mathrm{ab}$ & 67.1 fghijk & 35.8 cdef & $1.5 \mathrm{ab}$ & 42.7 fghij & $22.1 \mathrm{c}$ & $29.0 \mathrm{~b}$ \\
\hline MS2 & Claforan $^{\circledR}$ & 400 & $4.3 \mathrm{ab}$ & $71.6 \mathrm{ijk}$ & 38.0 cdef & 11.9 bcde & $1.2 \mathrm{ab}$ & $6.6 \mathrm{~b}$ & $22.3 \mathrm{~b}$ \\
\hline MS3 & Claforan $^{\circledR}$ & 800 & $0 \mathrm{a}$ & 56.8 efghij & $28.4 \mathrm{c}$ & $0.8 \mathrm{ab}$ & $0 \mathrm{a}$ & $0.4 \mathrm{a}$ & $14.4 \mathrm{a}$ \\
\hline MS4 & Timentin & 100 & 37.4 de & $77.5 \mathrm{jk}$ & $57.5 \mathrm{~g}$ & $17.6 \mathrm{cdef}$ & 46.6 ghij & 32.1 cde & $44.8 \mathrm{~d}$ \\
\hline MS5 & Timentin & 200 & $16.8 \mathrm{bcd}$ & $89.2 \mathrm{k}$ & $53.0 \mathrm{efg}$ & 26.5 defgh & 80.61 & $53.6 \mathrm{fg}$ & $53.3 \mathrm{de}$ \\
\hline MS6 & Amoxicillin & 200 & 30.2 cde & $81.6 \mathrm{jk}$ & $56.0 \mathrm{fg}$ & 30.6 efgh & $68.4 \mathrm{jkl}$ & $49.5 \mathrm{efg}$ & $52.8 \mathrm{de}$ \\
\hline MS7 & Amoxicillin & 400 & $10.9 \mathrm{bc}$ & $87.0 \mathrm{k}$ & 54.4 defg & 6.7 abcd & $68.4 \mathrm{ijkl}$ & 37.6 cdef & $46.0 \mathrm{~cd}$ \\
\hline MS8 & Amoxiclav $^{\circledR}$ & 400 & $10.9 \mathrm{bc}$ & 70.3 hijk & 46.1 cdefg & $77.8 \mathrm{kl}$ & $100 \mathrm{mn}$ & $88.9 \mathrm{i}$ & $67.5 \mathrm{f}$ \\
\hline MS9 & Amoxiclav $^{\circledR}$ & 800 & $6.7 \mathrm{ab}$ & 67.1 ghijk & 36.9 cdef & 55.7 hijkl & $100 \mathrm{n}$ & $77.9 \mathrm{hi}$ & 57.4 ef \\
\hline $\begin{array}{c}\text { Mean } \\
\text { (explant) }\end{array}$ & - & & $13.5 \mathrm{a}$ & $74.2 \mathrm{~b}$ & - & $25.5 \mathrm{a}$ & $56.4 \mathrm{~b}$ & - & - \\
\hline $\begin{array}{c}\text { Mean } \\
\text { (genotype) }\end{array}$ & - & & & $43.9 \mathrm{a}$ & & & $40.9 \mathrm{a}$ & & - \\
\hline
\end{tabular}

Means followed by the same letter are not significantly different at $\alpha=0.05$ according to the Duncan's multiple range test. Data were $\arcsin \sqrt{\mathrm{X}}$ transformed prior to statistical analysis. ${ }^{1}$ Influence of culture medium component and explant type on the shoot organogenesis frequency. ${ }^{2}$ Influence of culture medium component and genotype on the shoot organogenesis frequency. ${ }^{3}$ Influence of culture medium component on the shoot organogenesis frequency. ${ }^{4}$ Influence of explant type on the shoot organogenesis frequency. ${ }^{5}$ Influence of genotype on the shoot organogenesis frequency.

Table 3. The effects of genotype, explant type, and culture medium components on the average number of tomato shoots produced per explant in vitro.

\begin{tabular}{|c|c|c|c|c|c|c|c|c|c|}
\hline \multirow{3}{*}{$\begin{array}{l}\text { Culture } \\
\text { Medium }\end{array}$} & \multirow{3}{*}{\multicolumn{2}{|c|}{$\begin{array}{l}\text { Antibiotic and Its } \\
\text { Concentration, } \\
\text { mg L L-1 }^{-1}\end{array}$}} & \multicolumn{7}{|c|}{ Average Number of Shoots per Explant } \\
\hline & & & \multicolumn{3}{|c|}{ cv. Moryana } & \multicolumn{3}{|c|}{ cv. Rekordsmen } & \multirow{2}{*}{$\begin{array}{c}\text { Mean } \\
\text { (Culture } \\
\text { Medium) } \\
\end{array}$} \\
\hline & & & Hypocotyls & Cotyledons & Mean $^{2}$ & Hypocotyls & Cotyledons & Mean & \\
\hline MS1 & \multicolumn{2}{|c|}{-} & $1.9^{1} \mathrm{bc}$ & 2.0 bcde & $2.0 \mathrm{bcd}$ & $1.3 \mathrm{ab}$ & 2.3 bcde & $1.8 \mathrm{abc}$ & $1.9 \mathrm{ab}$ \\
\hline MS2 & Claforan ${ }^{\circledR}$ & 400 & $1.6 \mathrm{ab}$ & 3.7 ghi & 2.7 bcdefg & 2.6 bcde & $1.5 \mathrm{abcd}$ & 2.0 bcde & $2.4 \mathrm{bc}$ \\
\hline MS3 & Claforan ${ }^{\circledR}$ & 800 & $1.0 \mathrm{a}$ & 2.3 bcdef & $1.7 \mathrm{ab}$ & $1.3 \mathrm{ab}$ & $1.0 \mathrm{a}$ & $1.1 \mathrm{a}$ & $1.4 \mathrm{a}$ \\
\hline MS4 & Timentin & 100 & 3.0 cdefghi & $5.6 \mathrm{j}$ & $4.3 \mathrm{jkl}$ & 2.0 abcde & 2.3 bcde & 2.2 bcdef & $3.2 \mathrm{~cd}$ \\
\hline MS5 & Timentin & 200 & 2.9 cdefghi & $4.3 \mathrm{ij}$ & 3.6 gh6ijk & 2.9 cde & $5.3 \mathrm{fgh}$ & $4.1 \mathrm{ijk}$ & $3.8 \mathrm{~d}$ \\
\hline MS6 & Amoxicillin & 200 & 2.6 bcdefg & 3.5 fghi & 3.0 defghi & $3.0 \mathrm{de}$ & $3.5 \mathrm{efg}$ & 3.3 fghij & $3.1 \mathrm{~cd}$ \\
\hline MS7 & Amoxicillin & 400 & 2.2 bcde & 3.2 efghi & 2.7 cdefg & 2.0 abcde & $9.2 \mathrm{i}$ & 5.61 & $4.2 \mathrm{~d}$ \\
\hline MS8 & Amoxiclav $^{\circledR}$ & 400 & $2.0 \mathrm{bcd}$ & 3.1 defghi & 2.6 bcdefg & $3.2 \mathrm{e}$ & $6.3 \mathrm{~h}$ & $4.8 \mathrm{kl}$ & $3.7 \mathrm{~d}$ \\
\hline MS9 & Amoxiclav $^{\circledR}$ & 800 & $2.3 \mathrm{bcdef}$ & $4.0 \mathrm{hi}$ & 3.1 efghij & 2.7 bcde & $5.3 \mathrm{gh}$ & 4.0 hijk & $3.6 \mathrm{~d}$ \\
\hline $\begin{array}{c}\text { Mean } \\
\text { (explant) }\end{array}$ & \multicolumn{2}{|c|}{ - } & $2.0 \mathrm{a}$ & $3.5 \mathrm{~b}$ & - & $2.0 \mathrm{a}$ & $4.0 \mathrm{~b}$ & - & - \\
\hline $\begin{array}{c}\text { Mean } \\
\text { (genotype) }\end{array}$ & \multicolumn{2}{|c|}{ - } & \multicolumn{3}{|c|}{$2.8 \mathrm{a}$} & \multicolumn{3}{|c|}{$3.0 \mathrm{a}$} & - \\
\hline
\end{tabular}

Means followed by the same letter are not significantly different at $\alpha=0.05$ according to the Duncan's multiple range test. The average number of shoots per explant were $\sqrt{\mathrm{X}+1}$ transformed prior ANOVA. ${ }^{1}$ Influence of culture medium component and explant type on the number of shoots per explant. ${ }^{2}$ Influence of culture medium component and genotype on the number of shoots per explant. ${ }^{3}$ Influence of culture medium component on the number of shoots per explant. ${ }^{4}$ Influence of explant type on the number of shoots per explant. ${ }^{5}$ Influence of genotype on the number of shoots per explant.

Both stimulatory and inhibitory effects of $\beta$-lactam antibiotics were noted when evaluating the average number of regenerated shoots per explant (Table 3). Compared to the control, a significant increase in the number of regenerated shoots per hypocotyl explant (2.89-3.24) was found on MS5, MS6, and MS8 culture media only for the Rekodsmen cultivar. For cotyledon explants of both tomato cultivars, the stimulatory effect was 
established for most variants of culture media. At the same time, the average number of shoots produced per cotyledon explant for Moryana and Rekodsmen cultivars varied from 3.2 and 5.6 to 5.6 and 9.2, respectively.

Thus, on average for both explant types and tomato genotypes, the addition of timentin, amoxicillin, and Amoxiclav ${ }^{\circledR}$ to t MS1 culture medium increased the shoot organogenesis frequency, as well as the number of shoots produced per explant. It was found that cotyledons of both tomato genotypes were characterized by a higher frequency of shoot organogenesis (74.2\% and 56.4\% for Moryana and Rekodsmen cultivars, respectively) and average shoot number produced per explant (4.1 and 3.5 for Moryana and Rekodsmen cultivars, respectively) than hypocotyl segments. Thus, it is not found significant differences between tomato genotypes on regenerative capacity for both explant types and variants of culture media.

\subsection{The Effects of Different $\beta$-Lactam Antibiotics on A. tumefaciens Growth Inhibition In Vitro}

The results shown in Figure 3 and Figure S1 represent the antibacterial activity of different $\beta$-lactam antibiotics in solidified Luria-Bertani (LB) medium against growth inhibition of $A$. tumefaciens strain AGL0 using agar disk-diffusion assay. Depending on the concentration and type of antibiotic, the diameter of growth inhibition zones varied from 11.7 to $43.9 \mathrm{~mm}$. The higher antibiotic concentration in LB medium increased diameter of the growth inhibition zones. Thus, the antibacterial activity of tested $\beta$-lactam antibiotics was arranged in the following order: timentin $>$ Claforan $^{\circledR}>$ amoxicillin $\geq$ Amoxiclav $^{\circledR}$.

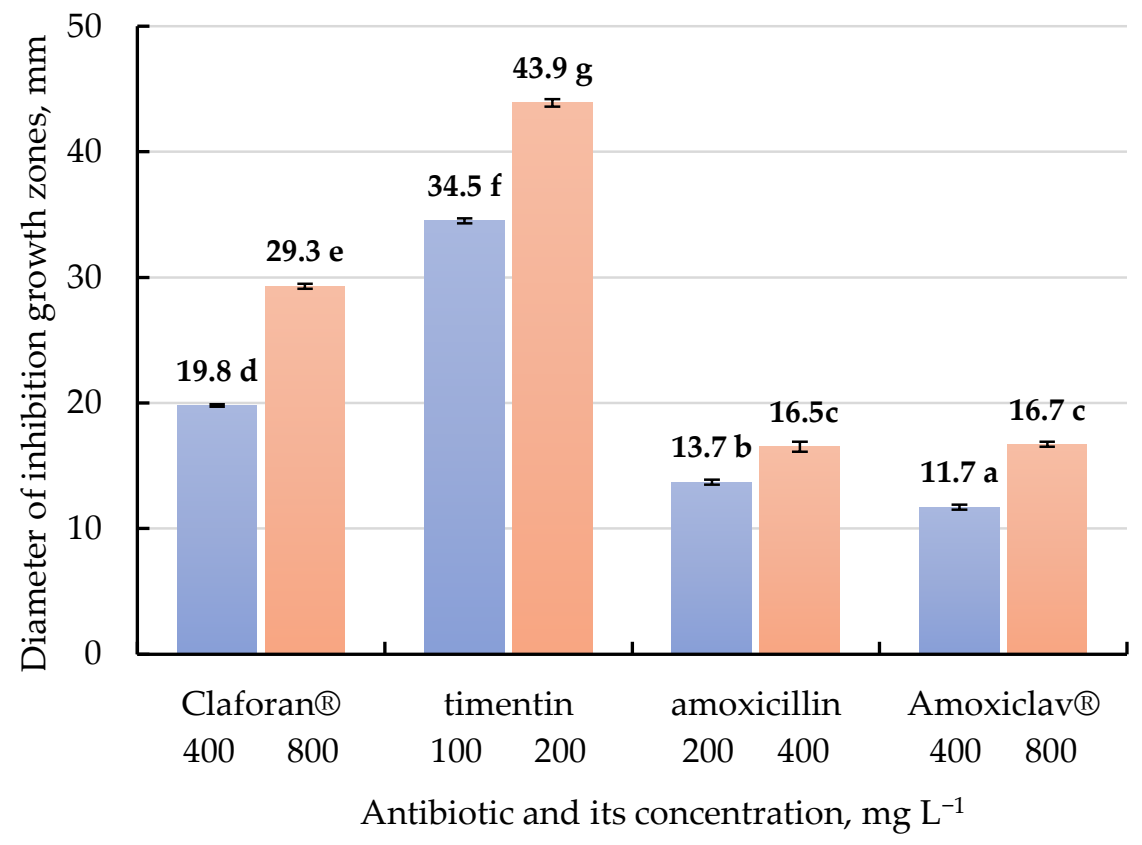

Figure 3. Influence of different $\beta$-lactam antibiotics on A. tumefaciens growth inhibition (strain AGL0) using agar disk-diffusion assay. The figure shows mean values \pm standard errors. Means followed by the same letter are not significantly different at $\alpha=0.05$ according to the Duncan's multiple range test.

\section{Discussion}

Optimization of an effective protocol for tomato regeneration system in vitro as well as Agrobacterium-mediated transformation is still routine, since morphogenesis efficiency is largely dependent on genetic, physiological, and physical factors $[1,5,10-17,21-23]$. To suppress bacterial infection during the introduction of plant material into an in vitro culture, clonal micropropagation and Agrobacterium-mediated transformation plant material is long-term subcultured on a medium supplemented with antibiotics. This is because the cultivation of explants on nutritionally-rich media stimulates an increase of microor- 
ganism titer in the cytoplasm, intercellular spaces, and vascular tissues, which ultimately leads to the visible manifestation after n-number of passages, necrosis, and death of plant tissue. Agrobacterium contamination of plant tissues does not allow the detection of the true transgenic status of transformants by molecular genetic techniques. In addition, endophytic bacterial microorganisms associated with the plant tissue culture (latent bacterial contamination) determine the regeneration and transformation capacity $[34,35]$.

The comparative effect of various types and concentrations of $\beta$-lactam antibiotics to inhibit the Agrobacterium growth in vitro [36,37] and in planta [38-42], as well as on tomato morphogenesis responses [43-45], has been previously shown. In pioneering works devoted to the introduction of foreign DNA into the tomato genome by Agrobacteriummediated transformation, the authors used classical carbenicillin [46,47]. With the advent of next generation semi-synthetic $\beta$-lactams, such as cefotaxime $\left(\right.$ Claforan $\left.{ }^{\circledR}\right)[22,48,49]$, cefoxitin (mefoxin) [39], meropenem and imipenem [38,39], moxalactam [39], amoxicillin (Augmentin ${ }^{\circledR}$, Amoxiclav $^{\circledR}$, Clavamox $^{\circledR}$ ) $[42,50]$, and ticarcillin $\left(\right.$ Timentin $\left.{ }^{\circledR}\right)[10,41,51]$, singly or coupled with $\beta$-lactamase inhibitor (clavulanic acid), they have been utilized at different concentrations to eliminate bacteria during tomato transformation. A number of studies have demonstrated the effective combined use of two overgrowth-control antibiotics in tomato regeneration medium, e.g., $250 \mathrm{mg} \mathrm{L}^{-1}$ cefotaxime and $500 \mathrm{mg} \mathrm{L}^{-1}$ carbenicillin [23], as well as $250 \mathrm{mg} \mathrm{L}^{-1}$ cefotaxime and ticarcillin [40]. In addition to antimicrobial activity, antibiotics have a pronounced positive effect on the regeneration capacity in tomato tissue culture [40-45] and many other crops [52-56]. However, their role in stimulating the morphogenesis in vitro is not fully understood, but it has been assumed that the antibiotics or degradation products mimic PGRs, since some of them possess an auxin-like structure $[52,56,57]$.

In our earlier experiments, we evaluated different PGRs on callus induction and shoot organogenesis in vitro from hypocotyl and cotyledon explants of Rekordsmen cultivar and other commercial tomato genotypes $[10,11]$. In order to reveal the possible stimulating and inhibiting effects of various $\beta$-lactam antibiotics on tomato morphogenesis, in this study, we used the MS culture medium supplemented with $5 \mathrm{mg} \mathrm{L}^{-1} 6-\mathrm{BA}$ and $0.1 \mathrm{mg} \mathrm{L}^{-1}$ IAA (MS1), which does not provide high efficiency of shoot regeneration. As a result, culture media were identified that negatively (MS3 medium supplemented with $800 \mathrm{mg} \mathrm{L}^{-1}$ of cefotaxime) or positively (MS8 supplemented with $400 \mathrm{mg} \mathrm{L}^{-1}$ of Amoxiclav ${ }^{\circledR}$ ) influenced the callus formation of Rekordsmen cultivar. Several studies have demonstrated no obvious inhibition effect of cefotaxime on callus induction and growth in tomato [41], but it significantly reduced shoot regeneration [41,42,45,49,50]. Kazemi et al. [49] suggested that reducing the negative effects of cefotaxime on tomato regeneration frequency and shoot number per cotyledonary explant was detected when replacing FeEDTA (iron chelate) with FeEDDHA (iron $\left(3^{+}\right)$[ethylenediamine-N, $\mathrm{N}^{\prime}$-bis(hydroxyphenylacetic acid)]) in MS culture medium. In contrast, a stimulatory effect of cefotaxime in maize callus cultures [53] and carrot protoplast cultures [56] has been previously demonstrated. In our case, the addition of Claforan ${ }^{\circledR}$ at different concentrations in the MS1 culture medium dramatically reduced shoot organogenesis or completely inhibited the regenerative process.

Furthermore, our study identified different concentrations of $\beta$-lactams, such as timentin, amoxicillin, and Amoxiclav ${ }^{\circledR}$, that significantly increased the shoot organogenesis frequency, as well as the number of shoots produced per explant from tomato tissue culture. It was found that clavulanic acid, which is part of the commercial antibiotic Amoxiclav ${ }^{\circledR}$, significantly increased the shoot regeneration frequency from cotyledon and hypocotyl explants of Rekordsmen tomato cultivar. A stimulatory effect of ticarcillin and amoxicillin in tomato tissue cultures has also been previously shown [41-45,50]. Since ticarcillin is metabolized to phenylacetic acid, a naturally occurring weak auxin [57], increasing timentin concentration might improve tomato regeneration potential. Clavulanic acid is rapidly hydrolyzed at a $25^{\circ} \mathrm{C}$ via the reactive amino ketone (1-amino-2-oxo-butan-4-ol) to pyrazine end-products (2,5-bis(2-hydroxyethyl)pyrazine, 3-carboxyethyl-2,5-bis(2-hydroxyethyl)pyrazine, and 3-ethyl-2,5-bis(2-hydroxyethyl)pyrazine) as well as carbon dioxide and acetaldehyde [58,59]. 
The stimulating effect of clavulanic acid on morphogenetic responses of tomato is most likely associated with direct action or products of its degradation as catalysts alone or combined with other $\beta$-lactam antibiotics or PGRs. Enhanced regenerative capacity may be due to stimulation of these antibiotics on the number of meristematic zones formed in callus tissue, from which subsequent shoot organogenesis occurred. Thus, the obtained results agree with the previously presented data that plant sensitivity to antibiotics usually is species-, genotype-, or even tissue-specific and mainly depends on concentrations, growth conditions and culture system.

Agar disk-diffusion assay is the official routine in vitro method used in many clinical trials and laboratory testing for antimicrobial susceptibility evaluation of antibiotics and other protective compounds [60-63]. With this assessment method, we evaluated the effectiveness of four $\beta$-lactam antibiotics on the growth elimination of $A$. tumefaciens strain AGL0 at concentrations that are most often applied in tomato transformation. As a result, the maximum diameter of growth inhibition zones was identified using $200 \mathrm{mg} \mathrm{L}^{-1}$ timentin $(43.9 \mathrm{~mm})$. The in vitro antibacterial activity of tested $\beta$-lactam antibiotics was arranged in the following order: timentin $>$ Claforan $^{\circledR}>$ amoxicillin $\geq$ Amoxiclav $^{\circledR}$. On the basis of agar disk-diffusion assay, the high efficiency of timentin at minimal concentrations (50 mg L ${ }^{-1}$ ) in inhibiting the growth of A. tumefaciens strain EHA105 compared with carbenicillin and cefotaxime was previously demonstrated [37]. Determination of the minimum inhibitory concentration (MIC) and minimum bactericidal concentration (MBC) revealed a high in vitro antibacterial activity of meroperem (carbapenem antibiotic) against A. tumefaciens strains AGL0, LBA4404, C58, and EHA101 [36,38]. Ogawa and Mii [36] found that the antibacterial activities of $12 \beta$-lactams tested against strain LBA4404 were equal to or higher than those tested against strain EHA101. The mentioned above indicates the need for screening the type and concentration of antibiotic depending on the Agrobacterium strain, taking into account its negatively effects on the morphogenesis of plant tissue cultures.

\section{Materials and Methods}

\subsection{Plant Material}

Two commercial tomato (S. lycopersicum L.) cultivars (Rekordsmen and Moryana) were used in the experiment for obtaining donor seedlings. Tomato seeds were kindly provided by the All-Russian Research Institute of Irrigated Vegetable, Melon, and Ground Growing (Astrakhan oblast, Kamyziyak, Russia).

\subsection{Explant Source, Antibiotics, and Culture Conditions}

The seeds were surface sterilized in $96 \%$ ethanol for $30 \mathrm{~s}$ and in $20 \%$ solution $(v / v)$ of the commercial bleach 'Ace' with a few drops of Tween-20 for $7 \mathrm{~min}$, then rinsed with sterilized distilled water five times for $1 \mathrm{~min}$ each. After surface sterilization, the seeds were cultured on MS basal medium [64] without PGRs supplemented with 3\% (w/v) sucrose (PanReac AppliChem, Madrid, Spain) and 0.7\% (w/v) agar (PhytoTechnology Laboratories, Lenexa, KS, USA). The $\mathrm{pH}$ was adjusted with $1 \mathrm{M} \mathrm{KOH}$ solution to 5.7-5.8 before autoclaving. The culture medium was sterilized by autoclaving at $121{ }^{\circ} \mathrm{C}$ and $1.1 \mathrm{~atm}$ for $20 \mathrm{~min}$.

Whole cotyledons with 2-3 mm petioles as well as hypocotyl segments (approximately $10-15 \mathrm{~mm}$ in length) excised from the middle part of 10-12-day-old aseptic seedlings were used as explants. For callus induction and shoot regeneration, the explants were cultivated on agar-solidified MS medium supplemented with $5 \mathrm{mg} \mathrm{L}^{-1}$ 6-benzylaminopurine (6-BA) (Sigma-Aldrich, St. Louis, MI, USA) and $0.1 \mathrm{mg} \mathrm{L}^{-1}$ indole-3-acetic acid (IAA) (SigmaAldrich, St. Louis, MI, USA) (MS1) as well as on MS1 culture medium containing four types of $\beta$-lactam antibiotics at different concentrations (MS2-MS9) (Table 1).

Antibiotics and PGRs were dissolved in distilled water, filter-sterilized $(0.22 \mu \mathrm{m}$ Millipore, Burlington, MA, USA), and stored until use at $-20^{\circ} \mathrm{C}$. They were added after autoclaving to a culture medium cooled to $45^{\circ} \mathrm{C}$. Hypocotyl segments and cotyledons were placed in the Petri dishes horizontally and with the abaxial surface in contact with the 
culture medium, respectively. The explants were subcultured to fresh medium every 15 days. Donor seedlings and explants were kept in a climatic test chamber (Sanyo WLR-351H, Osaka, Japan) at $25 \pm 2{ }^{\circ} \mathrm{C}$ under a 16-h photoperiod and light intensity of $65 \mu \mathrm{mol} \mathrm{m}^{-2} \mathrm{~s}^{-1}$.

\subsection{Histological Analysis of Callus Tissue}

Fragments of callus tissue formed from hypocotyl and cotyledon explants on MS1 culture media supplemented with $5 \mathrm{mg} \mathrm{L}^{-1} 6$-BA and $0.1 \mathrm{mg} \mathrm{L}^{-1}$ IAA were fixed for $24 \mathrm{~h}$ in $2.5 \%$ glutaraldehyde (Merck, Darmstadt, Germany) dissolved in 0.1 M Sorensen's phosphate buffer ( $\mathrm{pH} 7.2$ ) with $1.5 \%$ sucrose. Then, the samples were washed, post-fixed in $1 \% \mathrm{OsO} 4$ (Sigma-Aldrich, USA), and dehydrated in ethanol of increasing concentrations $(30 \%, 50 \%, 70 \%, 96 \%$, and $100 \%)$ and in propylene oxide (Fluka, Hamburg, Germany). The samples were embedded in mixture of Epon-812 and Araldite (Merck, Germany) according to the standard procedure. For light microscopy, semi-thin sections $(1-2 \mu \mathrm{m})$ were prepared using glass knives and ultramicrotome LKB-V (LKB, Sweden), placed on glass slides, and embedded in epoxide resin. Samples were photographed using Olympus BX51 microscope (Olympus, Tokyo, Japan) with Color View II camera (Soft Imaging System, Münster, Germany).

\subsection{Agar Disk-Diffusion Method}

The agar disk-diffusion method was used to determine the Agrobacterium growth inhibition in vitro by various antibiotics at different concentrations. A. tumefaciens strain AGL0 was grown in a $250-\mathrm{mL}$ capacity conical glass flask overnight at $28^{\circ} \mathrm{C}$ in $50 \mathrm{~mL}$ of LB liquid medium [65] containing $50 \mathrm{mg} \mathrm{L}^{-1}$ rifampicin in a rotary shaker (150 rpm). An overnight culture of AGL0 strain was resuspended to $\mathrm{OD}_{600}=0.6$ and subsequently diluted 1000 times with LB liquid medium. Then, a diluted Agrobacterium suspension was inoculated on the surface of glass Petri dishes $(100 \times 15 \mathrm{~mm})$ containing $25 \mathrm{~mL}$ agarsolidified LB medium supplemented with $50 \mathrm{mg} / \mathrm{L}$ rifampicin. To the sterile filter paper discs (10 mm in diameter), $50 \mu \mathrm{L}$ solutions of different antibiotic concentrations such as Claforan $^{\circledR}$, timentin, amoxicillin, and Amoxiclav ${ }^{\circledR}$ (Table 1) were added. A sterile disc without antibiotic was used as negative control. Subsequently, filter paper discs were placed on the surface of agar-solidified LB medium. The Petri dishes were incubated at $37^{\circ} \mathrm{C}$ for $48 \mathrm{~h}$, then diameters of inhibition growth zones were measured.

\subsection{Accounting Data and Statistical Analysis}

To assess the effect of antibiotics on tomato morphogenesis, the frequency of callus formation and shoot organogenesis as well as the average number of shoots per explant were determined using following formulas:

Callus formation frequency $(\%)=$ [number of explants successfully forming callus $/$ total number of explants] $\times 100$;

Shoot organogenesis frequency $(\%)=$ [number of regenerating explants/number of explants forming callus] $\times 100$;

Average number of shoots per explant $=$ [shoot number $/$ number of regenerating explants $] \times 100$.

Evaluation of the morphogenetic potential was carried out on the 45th day of cultivation. Each variant of treatment was performed in three replications. For one replication, 10 cotyledons and 15 hypocotyl segments per each variant of culture medium were used. Experimental data were assessed at $5 \%$ significance level using the analysis of variance (ANOVA) and Duncan's multiple range tests with AGROS software (version 2.11, Russia). Data of callus formation and shoot organogenesis (\%) were $\arcsin \sqrt{X}$ transformed prior to statistical analysis. The average number of shoots per explant were $\sqrt{X+1}$ transformed prior ANOVA [66].

To assess the effect of varying antibiotic concentrations for eliminating Agrobacterium, the diameters of inhibition growth zones were measured. The agar disk-diffusion test was 
performed three times in three biological replicates (three Petri dishes with three filter paper discs for each variant).

\section{Conclusions}

In the presented article, we estimated a comparative effect of various $\beta$-lactam antibiotics, such as cefotaxime, amoxycillin, and ticarcillin at different concentrations, on in vitro callus induction and shoot organogenesis from hypocotyl and cotyledon explants of two tomato cultivars (Rekordsmen, Moryana). Additionally, the growth inhibition of A. tumefaciens AGL0 strain according to agar disk-diffusion assay was implemented. As a result, both stimulatory (timentin, amoxicillin, and Amoxiclav ${ }^{\circledR}$ ) and inhibitory $\left(\right.$ Claforan ${ }^{\circledR}$ ) effects of $\beta$-lactam antibiotics on in vitro morphogenetic responses of tomato were noted. It was found that clavulanic acid, which is part of the commercial antibiotic Amoxiclav ${ }^{\circledR}$, significantly increased the shoot regeneration frequency from cotyledon and hypocotyl explants of Rekordsmen tomato cultivar. The stimulating effect of clavulanic acid on morphogenetic responses of tomato is most likely associated with direct action or products of its degradation as catalysts alone or combined with other $\beta$-lactam antibiotics or PGRs. Thus, the obtained results agree with the previously presented data that plant sensitivity to antibiotics usually is genotype- and tissue-specific and mainly depends on its concentrations. According to agar disk-diffusion assay, the maximum diameter of growth inhibition zones $\left(43.9 \mathrm{~mm}\right.$ ) was identified using $200 \mathrm{mg} \mathrm{L}^{-1}$ timentin. The in vitro antibacterial activity of tested $\beta$-lactam antibiotics was arranged in the following order: timentin $>$ Claforan ${ }^{\circledR}>$ amoxicillin $\geq$ Amoxiclav ${ }^{\circledR}$. Thus, to suppress the growth of internal and latent bacterial infection associated with tomato plant tissue culture, as well as for tomato transformation of Moryana and Rekordsmen cultivars by A. tumefaciens strain AGL0, we recommend adding $100-200 \mathrm{mg} \mathrm{L}^{-1}$ timentin or $400-800 \mathrm{mg} \mathrm{L}^{-1}$ Amoxiclav $^{\circledR}$ to the culture medium.

Supplementary Materials: The following are available online at https:/ /www.mdpi.com/article/10 $.3390 /$ antibiotics $10060660 / \mathrm{s} 1$, Table S1: The results of three-way ANOVA test to evaluate the significance of culture medium components, tomato genotype and explant type on the callus formation frequency; Figure S1: Antibacterial activity of different $\beta$-lactam antibiotics on growth inhibition of A. tumefaciens strain AGL0 using agar disk-diffusion assay.

Author Contributions: N.V.V. and Y.I.D. conducted the experiments on tomato culture in vitro. A.O.B. and N.V.V. conducted the agar disk-diffusion assay. E.N.B. conducted the histological estimation of tomato callus tissue. M.R.K. participated in manuscript conceptualization and statistical analysis of experimental data and writing, reviewing, and editing of manuscript; approved the final manuscript for publication, and agreed to be accountable for all aspects of the manuscript. All authors have read and agreed to the published version of the manuscript.

Funding: The reported study was supported by assignments 0574-2019-002 (All-Russia Research Institute of Agricultural Biotechnology) and 18-118021490111-5 (Tsitsin Main Botanical Garden of Russian Academy of Sciences) of the Ministry of Science and Higher Education of the Russian Federation.

Institutional Review Board Statement: Not applicable.

Informed Consent Statement: Not applicable.

Data Availability Statement: Data sharing is not applicable to this article.

Acknowledgments: The authors are grateful to the All-Russian Research Institute of Irrigated Vegetable, Melon and Ground Growing for providing tomato seeds of the Moryana and Rekodsmen cultivars for experiments.

Conflicts of Interest: The authors declare no conflict of interest. 


\section{References}

1. Gerszberg, A.; Hnatuszko-Konka, K.; Kowalczyk, T.; Kononowicz, A.K. Tomato (Solanum lycopersicum L.) in the service of biotechnology. Plant Cell Tiss. Organ Cult. 2015, 120, 881-902. [CrossRef]

2. Hwang, H.H.; Yu, M.; Lai, E.M. Agrobacterium-mediated plant transformation: Biology and applications. Arab. Book 2017, 2017, 1-31. [CrossRef] [PubMed]

3. Ruma, D.; Dhaliwal, M.S.; Kaur, A.; Gosal, S.S. Transformation of tomato using biolistic gun for transient expression of the B-glucuronidase gene. Indian J. Biotechnol. 2009, 8, 363-369.

4. Abu-El-Heba, G.A.; Hussein, G.M.; Abdalla, N.A. A rapid and efficient tomato regeneration and transformation system. Landbauforsch. Volkenrode 2008, 58, 103.

5. Vinoth, S.; Gurusaravanan, P.; Jayabalan, N. Optimization of factors influencing microinjection method for Agrobacterium tumefaciens-mediated transformation of tomato. Appl. Biochem. Biotechnol. 2013, 169, 1173-1187. [CrossRef] [PubMed]

6. Nakata, K.; Tanaka, H.; Yano, K.; Takagi, M. An effective transformation system for Lycopersicon peruvianum by electroporation. Jpn. J. Breed. 1992, 42, 487-495. [CrossRef]

7. Ray, S.; Lahiri, S.; Halder, M.; Mondal, M.; Choudhuri, T.R.; Kundu, S. An efficient method of isolation and transformation of protoplasts from tomato leaf mesophyll tissue using the binary vector pCambia 1302. Int. Adv. Res. J. Sci. Eng. Technol. 2015, 2, 146-150.

8. Nicolia, A.; Andersson, M.; Hofvander, P.; Festa, G.; Cardi, T. Tomato protoplasts as cell target for ribonucleoprotein (RNP)mediated multiplexed genome editing. Plant Cell Tiss. Organ. Cult. 2021, 144, 463-467. [CrossRef]

9. Rao, A.Q.; Bakhsh, A.; Kiani, S.; Shahzad, K.; Shahid, A.A.; Husnain, T.; Riazuddin, S. The myth of plant transformation. Biotechnol. Adv. 2009, 27, 753-763. [CrossRef]

10. Khaliluev, M.R.; Kharchenko, P.N.; Dolgov, S.V. Development of regeneration system and study of the transformation potential of a commercial tomato variety. Russ. Agric. Sci. 2010, 36, 175-179. [CrossRef]

11. Khaliluev, M.R.; Bogoutdinova, L.R.; Baranova, G.B.; Baranova, E.N.; Kharchenko, P.N.; Dolgov, S.V. Influence of genotype, explant type, and component of culture medium on in vitro callus induction and shoot organogenesis of tomato (Solanum lycopersicum L.). Biol. Bull. 2014, 41, 512-521. [CrossRef]

12. Kumar, S.; Jindal, S.K.; Sarao, N.K.; Dhaliwal, M.S. Development of an efficient In vitro regeneration protocol in tomato (Solanum lycopersicum L.). Agric. Res. J. 2017, 54, 475-479. [CrossRef]

13. Rashid, R.; Bal, S.S. Effect of hormones on direct shoot regeneration in hypocotyl explants of tomato. Not. Sci. Biol. 2010, 2, 70-73. [CrossRef]

14. Devi, R.; Dhaliwal, M.S.; Gosal, S.S. In vitro direct plant regeneration protocol for tomato genotypes. Indian J. Horticult. 2013, 70, 369-372.

15. Saeed, W.; Naseem, S.; Gohar, D.; Ali, Z. Efficient and reproducible somatic embryogenesis and micropropagation in tomato via novel structures-Rhizoid Tubers. PLoS ONE 2019, 14, e0215929. [CrossRef] [PubMed]

16. Godishala, V.; Mangamoori, L.; Nanna, R. Plant regeneration via somatic embryogenesis in cultivated tomato (Solanum lycopersicum L.). J. Cell Tiss. Res. 2011, 11, 2521.

17. Ashakiran, K.; Chidambareswaran, M.; Govindasamy, V.; Sivankalyani, V.; Girija, S. Somatic embryogenesis for Agrobacterium mediated transformation of tomato-Solanum lycopersicum. L. Int. J. Biotechnol. Appl. 2011, 3, 72-79.

18. Trujillo-Moya, C.; Gisbert, C.; Vilanova, S.; Nuez, F. Localization of QTLs for in vitro plant regeneration in tomato. BMC Plant Biol. 2011, 11, 1-13. [CrossRef]

19. Basté, E.M.; Pratta, G.R.; Zorzoli, R. Genetic analysis of the in vitro culture response in tomato. Plant Cell Tiss. Organ Cult. 2007, 88, 233-239. [CrossRef]

20. Sánchez-López, J.; Atarés, A.; Jáquez-Gutiérrez, M.; Ortiz-Atienza, A.; Capel, C.; Pineda, B.; García-Sogo, B.; Yuste-Lisbona, F.J.; Lozano, R.; Moreno, V. Approaching the genetic dissection of indirect adventitious organogenesis process in tomato explants Plant Sci. 2021, 302, 110721. [CrossRef]

21. Lee, M.H.; Lee, J.; Jie, E.Y.; Choi, S.H.; Jiang, L.; Ahn, W.S.; Kim, C.Y.; Kim, S.W. Temporal and spatial expression analysis of shoot-regeneration regulatory genes during the adventitious shoot formation in hypocotyl and cotyledon explants of tomato (cv. Micro-Tom). Int. J. Mol. Sci. 2020, 21, 5309. [CrossRef]

22. Stavridou, E.; Tzioutziou, N.A.; Madesis, P.; Labrou, N.E.; Nianiou-Obeidat, I. Effect of different factors on regeneration and transformation efficiency of tomato (Lycopersicum esculentum) hybrids. Czech J. Gen. Plant Breed. 2019, 55, 120-127. [CrossRef]

23. Chetty, V.J.; Ceballos, N.; Garcia, D.; Narváez-Vásquez, J.; Lopez, W.; Orozco-Cárdenas, M.L. Evaluation of four Agrobacterium tumefaciens strains for the genetic transformation of tomato (Solanum lycopersicum L.) cultivar Micro-Tom. Plant Cell Rep. 2013, 32, 239-247. [CrossRef] [PubMed]

24. Enikeev, A.G.; Kopytina, T.V.; Semenova, L.A.; Natyaganova, A.V.; Gamanetz, L.V.; Volkova, O.D. Agrobacterial transformation as complex biotical stressing factor. J. Stress Physiol. Biochem. 2008, 4, 11-19.

25. Şen, A. Oxidative stress studies in plant tissue culture. In Antioxidant Enzyme; El-Missiry, M.A., Ed.; InTech: Rijeka, Croatia, 2012; pp. $59-88$.

26. Dolgikh, Y.I.; Stepanova, A.Y.; Trusova, S.V.; Chichkova, N.V.; Vartapetian, A.B. Mitochondria-targeted antioxidant provides for enhanced morphogenetic potential in plant tissue cultures. Russ. J. Plant Physiol. 2013, 60, 706-712. [CrossRef] 
27. Ahsan, N.; Lee, S.-H.; Lee, D.-G.; Anisuzzaman, M.; Alam, M.F.; Yoon, H.-S.; Choi, M.S.; Yang, J.-K.; Lee, B.H. The effects of wounding type, preculture, infection method and cocultivation temperature on the Agrobacterium-mediated gene transfer in tomatoes. Ann. Appl. Biol. 2007, 151, 363-372. [CrossRef]

28. Guo, M.; Zhang, Y.L.; Meng, Z.J.; Jiang, J. Optimization of factors affecting Agrobacterium-mediated transformation of Micro-Tom tomatoes. Genet. Mol. Res. 2012, 11, 661-671. [CrossRef]

29. Dan, Y.; Zhang, S.; Zhong, H.; Yi, H.; Sainz, M.B. Novel compounds that enhance Agrobacterium-mediated plant transformation by mitigating oxidative stress. Plant. Cell Rep. 2015, 34, 291-309. [CrossRef]

30. Pandey, N.; Cascella, M. Beta lactam antibiotics. In StatPearls; StatPearls Publishing: Treasure Island, FL, USA, 2020.

31. Zango, U.U.; Ibrahim, M.; Shawai, S.A.A. A review on $\beta$-lactam antibiotic drug resistance. MOJ Drug. Des. Dev. Ther. 2019, 3 , 52-58.

32. Saudagar, P.S.; Survase, S.A.; Singhal, R.S. Clavulanic acid: A review. Biotechnol. Adv. 2008, 26, 335-351. [CrossRef]

33. Cheng, Z.M.; Schnurr, J.A.; Kapaun, J.A. Timentin as an alternative antibiotic for suppression of Agrobacterium tumefaciens in genetic transformation. Plant Cell Rep. 1998, 17, 646-649. [CrossRef]

34. Dunaeva, S.E.; Osledkin, Y.S. Bacterial microorganisms associated with the plant tissue culture: Identification and possible role. Sel'skokhozyaistvennaya Biol. 2015, 50,3-15. [CrossRef]

35. Cheong, E.J.; Na, M.; Jeong, U. The effect of endophytic bacteria on in vitro shoot growth of Prunus yedoensis and its identification and elimination. Vitro Cell. Dev. Biol. Plant. 2019, 56, 200-206. [CrossRef]

36. Ogawa, Y.; Mii, M. Screening for highly active $\beta$-lactam antibiotics against Agrobacterium tumefaciens. Arch. Microbiol. 2004, 181, 331-336. [CrossRef] [PubMed]

37. Priya, A.M.; Pandian, S.K.; Manikandan, R. The effect of different antibiotics on the elimination of Agrobacterium and high frequency Agrobacterium-mediated transformation of indica rice (Oryza sativa L.). Czech J. Genet. Plant Breed. 2012, 48, 120-130. [CrossRef]

38. Farzaneh, A.; Adel, Y.; Ali, N.; Younes, G. Determine effective concentrations of $\beta$-lactam antibiotics against three strains of Agrobacterium tumefaciens and phytotoxicity on Tomato and Tobacco. Int. J. Agron. Plant. Prod. 2013, 11, $2919-2925$.

39. Ogawa, Y.; Mii, M. Meropenem and moxalactam: Novel $\beta$-lactam antibiotics for efficient Agrobacterium-mediated transformation. Plant Sci. 2007, 172, 564-572. [CrossRef]

40. Hu, W.; Phillips, G.C. A combination of overgrowth-control antibiotics improves Agrobacterium tumefaciens-mediated transformation efficiency for cultivated tomato (L. esculentum). Vitro Cell. Dev. Biol. Plant 2001, 37, 12-18. [CrossRef]

41. Ling, H.Q.; Kriseleit, D.; Ganal, M.W. Effect of ticarcillin/potassium clavulanate on callus growth and shoot regeneration in Agrobacterium-mediated transformation of tomato (Lycopersicon esculentum Mill.). Plant Cell Rep. 1998, 17, 843-847. [CrossRef] [PubMed]

42. Ieamkhang, S.; Chatchawankanphanich, O. Augmentin ${ }^{\circledR}$ as an alternative antibiotic for growth suppression of Agrobacterium for tomato (Lycopersicon esculentum) transformation. Plant Cell Tiss. Organ Cult. 2005, 82, 213-220. [CrossRef]

43. Mamidala, P.; Nanna, R.S. Influence of antibiotics on regeneration efficiency in tomato. Plant Omics J. 2009, 2, 135-140.

44. Costa, M.G.C.; Nogueira, F.T.S.; Figueira, M.L.; Otoni, W.C.; Brommonschenkel, S.H.; Cecon, P.R. Influence of the antibiotic timentin on plant regeneration of tomato (Lycopersicon esculentum Mill.) cultivars. Plant Cell Rep. 2000, 19, 327-332. [CrossRef] [PubMed]

45. Gerszberg, A.; Grzegorczyk-Karolak, I. Influence of selected antibiotics on the tomato regeneration in in vitro cultures. Not. Bot. Hort. Agrobot. 2019, 47, 558-564. [CrossRef]

46. Horsch, R.B.; Frye, J.E.; Hoffman, N.F.; Eichoholtz, D.; Rogers, S.G.; Fraley, R.T. A simple and general method for transferring genes into plants. Science 1985, 227, 1229-1231.

47. McCormick, S.; Niedermeyer, J.; Fry, J.; Barnason, A.; Horsch, R.; Fraley, R. Leaf disc transformation of cultivated tomato (L. esculentum) using Agrobacterium tumefaciens. Plant Cell Rep. 1986, 5, 81-84. [CrossRef] [PubMed]

48. Perveen, S.; Khan, T.A.; Shaheen, H.; Naz, R.; Hyder, M.Z.; Ijaz, B.; Saqlan Naqvi, S.M.; Yasmin, T. Morpho-physiological investigations in transgenic tomato (Solanum lycopersicum L.) over expressing OsRGLP1 gene. Vitro Cell. Dev. Biol. Plant 2021, 1-16. [CrossRef]

49. Kazemi, E.M.; Jonoubi, P.; Majd, A.; Pazhouhandeh, M. Reduction of negative effects of cefotaxime in tomato transformation by using FeEDDHA. Int. J. Farm. Alli. Sci. 2014, 3, 538-542.

50. Gulevich, A.A.; Kurenina, L.V.; Baranova, E.N. Application of a system for targeting Fe-dependent superoxide dismutase and choline oxidase enzymes to chloroplast as a strategy for effective plant resistance to abiotic stresses. Russ. Agric. Sci. 2018, 44, 118-123. [CrossRef]

51. Shpakovski, G.V.; Spivak, S.G.; Berdichevets, I.N.; Babak, O.G.; Kubrak, S.V.; Kilchevsky, A.V.; Aralov, A.V.; Slovokhotov, I.Y.; Shpakovski, D.G.; Baranova, E.N.; et al. A key enzyme of animal steroidogenesis can function in plants enhancing their immunity and accelerating the processes of growth and development. BMC Plant Biol. 2017, 17, 189. [CrossRef]

52. Mineykina, A.; Shumilina, D.; Bondareva, L.; Soldatenko, A.; Domblides, E. Effect of beta-lactam antibiotics on microspore embryogenesis in Brassica species. Plants 2020, 9, 489. [CrossRef]

53. Danilova, S.A.; Dolgikh, Y.I. The stimulatory effect of the antibiotic cefotaxime on plant regeneration in maize tissue culture. Russ. J. Plant Physiol. 2004, 51, 559-562. [CrossRef] 
54. Gambhir, G.; Kumar, P.; Srivastava, D.K. Effect of antibiotic sensitivity on different cultured tissues and its significance in genetic transformation of cabbage Brassica oleracea. Biosci. Biotechnol. Res. Comm. 2017, 10, 652-661. [CrossRef]

55. Stanišić, M.; Ninković, S.; Savić, J.; Ćosić, T.; Banjac, N. The effects of $\beta$-lactam antibiotics and hygromycin B on de novo shoot organogenesis in apple cv. Golden Delicious. Arch. Biol. Sci. 2018, 70, 179-190. [CrossRef]

56. Grzebelus, E.; Skop, L. Effect of $\beta$-lactam antibiotics on plant regeneration in carrot protoplast cultures. Vitro Cell. Dev. Biol. Plant 2014, 50, 568-575. [CrossRef]

57. Holford, P.; Newbury, H.J. The effects of antibiotics and their breakdown products on the in vitro growth of Antirrhinum majus. Plant Cell Rep. 1992, 11, 93-96. [CrossRef]

58. Brethauer, S.; Held, M.; Panke, S. Clavulanic acid decomposition is catalyzed by the compound itself and by its decomposition products. J. Pharm. Sci. 2008, 97, 3451-3455. [CrossRef]

59. Gómez-Ríos, D.; Ramírez-Malule, H.; Neubauer, P.; Junne, S.; Ríos-Estepa, R. Degradation kinetics of clavulanic acid in fermentation broths at low temperatures. Antibiotics 2019, 8, 6. [CrossRef]

60. Balouiri, M.; Sadiki, M.; Ibnsouda, S.K. Methods for in vitro evaluating antimicrobial activity: A review. J. Pharm. Anal. 2016, 6, 71-79. [CrossRef]

61. Schumacher, A.; Vranken, T.; Malhotra, A.; Arts, J.J.C.; Habibovic, P. In vitro antimicrobial susceptibility testing methods: Agar dilution to 3D tissue-engineered models. Eur. J. Clin. Microbiol. Infect Dis. 2018, 37, 187-208. [CrossRef]

62. Chiu, C.-T.; Lai, C.-H.; Huang, Y.-H.; Yang, C.-H.; Lin, J.-N. Comparative analysis of gradient diffusion and disk diffusion with agar dilution for susceptibility testing of Elizabethkingia anophelis. Antibiotics 2021, 10, 450. [CrossRef]

63. Böhm, M.E.; Razavi, M.; Flach, C.F.; Larsson, D.G. A Novel, Integron-regulated, class C $\beta$-lactamase. Antibiotics 2020, 9, 123. [CrossRef] [PubMed]

64. Murashige, T.; Skoog, F.A. Revised medium for rapid growth and bioassays with tobacco tissue culture. Physiol. Plant. 1962, 15, 473-497. [CrossRef]

65. Bertani, G. Studies on lysogenesis I. The mode of phage liberation by lysogenic Escherichia coli. J. Bacterial. 1951, 62, 293-300. [CrossRef] [PubMed]

66. Dospekhov, B.A. Methods of Field Experience; Agropromizdat: Moscow, Russia, 1985; p. 350. 